\title{
Evaluation of cellular toxicity in Hep G2 cell and endothelial cells on different medical biopolymer
}

\section{supports}

\begin{abstract}
Cellular responses to xenobiotic and environmental challenges are often cell cycle dependent and in view of the slow turn over in culture of endothelial cells, characterised by a long G1. In the context of the development of vascular models, a range of polyurethane materials as possible scaffolds and substrata have been evaluated for cell adhesion, proliferation and differentiation on the part of human hepatoma (HepG2) and endothelial cell. The aim of this study was to investigate the effect cell proliferation on toxicological end points. A comparison was made, for in vitro assessment of toxicity, between 12 polyurethanes (PU) [with respect to their cytocompatibility]. In our assessment growing population of cells were randomly grown on the different polyurethanes. Neutral red (NR), methy tetrazolium (MTT), and proliferation assays were used to determine the effect of exposure to test (polymer) and control surfaces. Results showed that there was generally a greater divergence between control and test responses for NR but not for MTT. NR proved more sensitive to extract exposure and this was significantly enhanced at a 1:3 medium ratio, rather than 1:1. For contact materials testing, the MTT response for HepG2 cells showed no correlation between synchronised and non-synchronised populations. Reproducibility and variate correlation was better for NR measures.
\end{abstract}

Conclusion: Reduced surface affinity and growth kinetics on the part of Hep G2 and endothelial cells grown on CarbothaneTM, may be associated with deleterious events characteristic of an inflammatory response. A significant increase in the results was obtained where the cells exposed to some test polymers with cell viability increasing to $120-140 \%$ relative to control cell survival. The cell proliferation assay revealed significant differences for some of the test materials for synchronised and nonsynchronised cell populations.

Keywords: cellular, toxicity, survival Hep G2 cell, endothelial cell, polyurethane, neutral red, MTT
Volume 4 Issue 3 - 2018

\section{Estella Tembe Fokunang,' Salwa Barkwan, ${ }^{2}$ Charles Fokunang,' Paul Tomkins ${ }^{2}$ \\ 'Department of Pharmacotoxicology, Faculty of Medicine and Biomedical Sciences, University of Yaounde, Cameroon ${ }^{2}$ Centre for Biopolymer \& Biomolecular Research (CBBR), School of Science, Athlone Institute of Technology, Ireland}

\section{Correspondence: Charles Fokunang, Department of Pharmacotoxicology, Faculty of Medicine and Biomedical Sciences, University of Yaounde, Cameroon, Email charlesfokunang@yahoo.co.uk}

Received: May 20, 2018 | Published: June 26, 2018

\section{Introduction}

There is an application driven need to identify and develop new materials for the biomedical industry and improve their physical and biocompatible properties. ${ }^{1,2}$ A combination of cell and molecular biology strategies applied to the rapid evaluation of cell behaviour in contact with materials may help to meet this objective. A group of soft and hard polyurethanes were first evaluated on the basis of cyto-compatibility endpoints Neutral red, (NR, MTT and BrdU uptake) using liver (HepG2) and vascular (endothelial) cell lines. ${ }^{3-5}$ By definition, biocompatibility is the ability of a material to perform with an appropriate host response on a specific application. The biocompatibility of biomaterials should be evaluated by quantitative methods. Only testing methods yielding quantitative results allow the biocompatibility "degree" of materials to be assessed and compared with that observed for different materials, including reference materials. ${ }^{6,7}$ Despite the relatively extensive nature of current test procedures, they are largely non-mechanistically driven and there are considerable opportunities to improve them. Since the late 1990s there has been considerable interest in applying gene expression methodology to the toxicology problem. ${ }^{8,9}$

\section{Cell culture}

All tissue culture manipulations were completed in a Class II safety cabinet, using sterile disposable plastic ware. Any fluids introduced into the culture vessels were either autoclaved or filtered $(0.2 \mu \mathrm{m})$. Aseptic technique was strictly adhered to in accordance with standard procedure, while at regular intervals the flow rate of the laminar flow cabinet was checked and sterility confirmed by standard nutrient plates. Water used in all assay and cell culture procedures was sourced from a milli-Q water purification system and was confirmed to be $18 \mathrm{M} \Omega$ qualities. This water was generally referred to as tissue culture grade water (TCG). ${ }^{10-13}$

\section{Preparation of culture media}

HepG2 cell lines were grown according to the ATCC/ECACC recommendation for cell type media selection. $100 \mathrm{ml}$ volumes of media were aseptically prepared as required (see Appendix I). Cells were maintained in a mix of 1:1 volume of Dulbecco's Minimum Eagle Medium (DMEM: Sigma), and nutrient mixture Hams F-12 medium containing 10\% foetal bovine serum (FBS). The content of serum is not well defined, but is known to contain amongst other entities growth factors and hormones..$^{14}$ Medium was supplemented with $100 \mathrm{U} / \mathrm{ml}$ penicillin and $100 \mu \mathrm{g} / \mathrm{ml}$ streptomycin to discourage the growth of microorganisms. The medium in all cases was supplemented with $200 \mathrm{mM}$ L-glutamine. L-glutamine is an essential amino acid that is required by virtually all-mammalian cells in culture. IU of amphotericin $\mathrm{B}$ was added as an anti fungal agent. It was reported that 
amphotericin B induces alterations in human cell gene transcription by activation of many cellular immune response proteins..$^{15}$ All cell lines employed in this study were maintained in a humidified incubator at $37^{\circ} \mathrm{C}$ under $95 \%$ air and $5 \% \mathrm{CO}_{2}$.

Human Microvascular Endothelial cells (HMEC) were obtained from TCS Cell works UK. TCS Cell works Microvascular Endothelial cell basal medium (ZHM-2946) is a bicarbonate buffered medium containing essential and non-essential amino acids, organic compounds, inorganic salts, trace minerals and vitamins. An antibiotic supplement was added with growth supplement (ZHS9939), which was supplied by the company. Finally, rat endothelial cells were purchased from Clonetics, BioWhittaker Inc, UK*. The growth medium EGM-2 Bulletkit included basal medium with all supplements and growth factors in separate, frozen aliquots (see Appendix AI). Adherent cells were grown to $80 \%$ confluence in tissue culture flasks $(75 \mathrm{~cm} 2)$ and were subcultured by discarding the spent medium, leaving the cells adhered to the bottom of the flask. The cells were then washed with $1 \mathrm{x} 5 \mathrm{ml}$ of phosphate buffered saline (PBS) and incubated at $37^{\circ} \mathrm{C}$ with $3 \mathrm{ml}$ of trypsin-EDTA until the cells had detached from the bottom of the cell culture flask. The trypsin cleaves adhesion molecules on the cell and EDTA chelates the calcium and magnesium ions essential for adhesion. Complete medium, $3 \mathrm{ml}$ was added to neutralise the effect of trypsin, and typically one tenth of cells were retained for future sub-culture.

\section{Routine cell culture quality control measures}

Cultures were examined by phase contrast microscopy after every manipulation and an aliquot of every batch of medium prepared was subjected to $24 / 48 \mathrm{hr}$ sterility check at $37 \mathrm{C}$ to exclude the presence of bacteria/fungal contamination. Characteristics of such contamination include extracelluler granularity, particulate matter floating in medium, which may resolve as 'rod' or 'cocci' with high power microscopy (e.g.x 400), turbid medium and rapid $\mathrm{pH}$ changes usually a decrease but some fungi may cause an increase reported by the internal indicator, phenol red. ${ }^{16}$ In practice, human endothelial cells were purchase from Bio Whittaker, but internal QC procedures in AIT laboratory established these cells to be of rat origin. Sterility Check: $5-10 \mathrm{mls}$ of medium was aseptically transferred to a $30 \mathrm{ml}$ universal incubated for $24 / 48 \mathrm{hr}$ at $37^{\circ} \mathrm{C}$ and examined for the presence of bacteria/fungal contamination.

\section{Determination of cell density}

The number of suspended or trypsinised "adherent" cells was estimated using an improved Neubauer haemocytometer. When cell suspension was introduced under the coverslip, it was possible to count the cells in a defined area using a microscope and a cell counter tally. In practice four large $1 \times 1 \mathrm{~mm}$ squares were counted observing the corner rule, which represents $0.1 \mathrm{~mm} 3$. The number of cells counted multiplied by 104 equals the number of cells perml $(\mathrm{cm} 3)$. So the final concentration expressed as $\mathrm{x} 106$ was determined from Number of cells $/ \mathrm{ml}=($ total number counted $) \mathrm{x} * \mathrm{DF} \mathrm{x} * 104$

Where $=* \mathrm{DF}=$ dilution factor, ${ }^{*} 104=$ conversion of $0.1 \mathrm{~mm} 3$ to $\mathrm{ml}$

\section{Cryopreservation \& recovery of cells}

All cell lines employed in this study were frozen and stored in liquid nitrogen. Cells in late log/pre confluent phase of growth were harvested by trypsinizing and re-suspended in a sterile universal. The cells were counted and 2 to $3 \times 106$ cells were centrifuged at 1000rpm in a bench-top centrifuge. Medium containing serum and DMSO were employed in the freezing process to prevent the formation of ice crystals inside cells that would otherwise cause cellular damage. The supernatant was discarded, and the cell pellet resuspended in $1 \mathrm{ml}$ of freezing mix ( $70 \%$ medium: $20 \%$ FBS: $10 \%$ DMSO). To achieve the optimal freeze rate depression of $-1^{\circ} \mathrm{C} / \mathrm{min}$ the vial were stored in an insulated polystyrene box over night at $-80^{\circ} \mathrm{C}$ prior to transfer to liquid nitrogen. ${ }^{17}$ The cryogenic vials were then transferred to liquid nitrogen for long term storage. Cells, which were preserved in liquid nitrogen, were recovered for culture in the following way; cryogenic vials were removed from liquid nitrogen storage, and thawed by placing them in a water bath at $37^{\circ} \mathrm{C}$ for four minutes until the cell suspension had thawed (this procedure was carried out as quickly as possible, as DMSO is cytotoxic to cells). The cells were then mixed with $20 \mathrm{ml}$ of pre-warmed medium $\left(37^{\circ} \mathrm{C}\right)$ to dilute the DMSO, and centrifuged for 3 minutes at $3000 \mathrm{rpm}$. The supernatant was discarded, the pellet re-suspend in fresh medium $(10 \mathrm{ml})$ and the cells cultured. Subsequently, the cell culture flask was checked $24 \mathrm{~h}$ later for cell growth. Medium was changed if it contained substantial amount of cell debris. Cells were subcultured twice prior to use. Passage number was always recorded.

\section{Viable cell counts (trypan blue staining)}

To distinguish between viable and non-viable cells on the haemocytometer, trypan blue staining was employed. Live cells exclude trypan blue stain, leaving them with a normal appearance under the microscope. Dead cells however take up the stain making them appear blue. An equal volume of cell suspension and stain $(0.4 \%)$ were mixed and loaded into to an improved Neubauer haemocytometer. The number of cells counted was multiplied by $2 \times 104$ to calculate cells $/ \mathrm{ml}$, thus taking into account the dilution factor upon addition of trypan blue. ${ }^{18}$

\section{Test materials}

Tissue culture methods for assessment of toxicity of biomaterials have been used and established many years ago. ${ }^{19-21}$ Many methodological efforts have been made to expose cells to the biomaterial in a way resembling an in vivo situation. Polymeric materials are known to leak constituents to their surroundings. As the leakage is dependent on the milieu, difference in toxicity may appear if the material is tested as a solid surface in direct contact with the cells, or as an extract. ${ }^{4,22,23}$ Testing materials by direct contact with cells has many drawbacks, for instance, large intrinsic variability due to the physical interference from the materials on the cell culture. Methods based on eluates of different kinds, are on the other hand less physiological in the sense that direct contact between materials and cells may be preferable. Thus, a combination of methods using both direct contact and eluate might be advantageous. The aim of this study was to find suitable methods to screen for toxicity of biomaterials intended for blood contact.

\section{MTT-Methyl (Microculture) Tetrazolium Assay}

The assay is based on the capacity of a mitochondrial dehydrogenase enzyme (succinate dehydrogenase) in living cells to convert the yellow water-soluble substrate 3-(4,5-dimethylthiazol2-yl)-2,5-diphenyl tetrazolium bromide (MTT) into a dark blue formazan product which is insoluble in water. ${ }^{24}$ 


\section{Method}

Cells were seeded after incubation for $24 \mathrm{~h}$ at $37^{\circ} \mathrm{C}$ with the test material, MTT was added to each will to a final concentration of $500 \mu \mathrm{g} / \mathrm{ml}$. Cells were stained for $3 \mathrm{~h}$ at $37^{\circ} \mathrm{C}$ and at the end of this period cells wells were washed with $200 \mathrm{ul}$ of PBS buffer 3 times. A destain solution of acidified isopropanol was added to solubilise the purple formazan crystals. Acidified isopropanol was prepared: $4 \mathrm{ml}$ $\mathrm{HCl}$ in $100 \mathrm{ml}$ of isopropanol. The absorbance was measured at $560 \mathrm{~nm}$ in an Anthos htIII plate reader.

\section{Unprocessed material testing}

Tissue culture methods for assessment of toxicity from biomaterials have been established for many years. Most applications have exposed cells to biomaterial in a way that simulate in vivo situations or alternatively employ a biomaterials extract. Polymeric materials are known to leak constituent to their surroundings. As the leakage is dependent on the milieu, differences in toxicity appear if the material is tested as solid material in direct contact with cells, or as an extract. ${ }^{24}$ A comparison was made, for in vitro assessment of toxicity using an extract method and a direct contact method with the cells. In the extract method $10 \mathrm{~g}$ of 12 different samples were incubated at $37^{\circ} \mathrm{C}$ for 4 weeks. Extraction was performed weekly and incubated at $50 \%$ and $25 \%(\mathrm{v} / \mathrm{v}$ in medium). The impact of dilution is accepted but the two alternatives of pre-concentration of extract or its utilisation to prepare powdered media were discounted. Water and PBS solutions

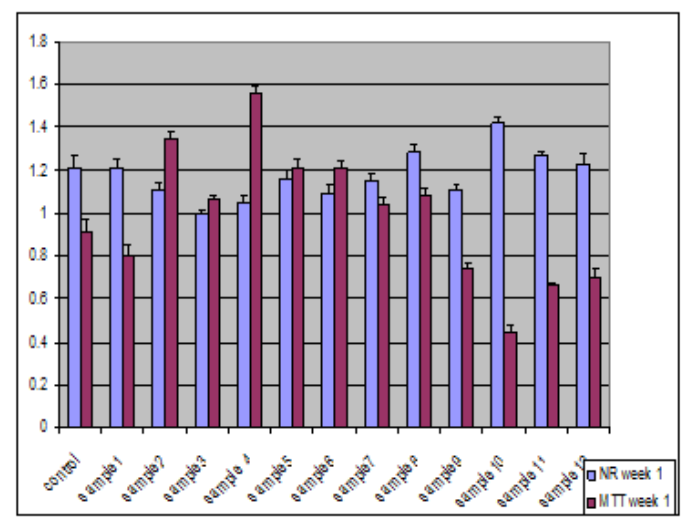

Week I responses of NR \& MTT assays for collected test materials

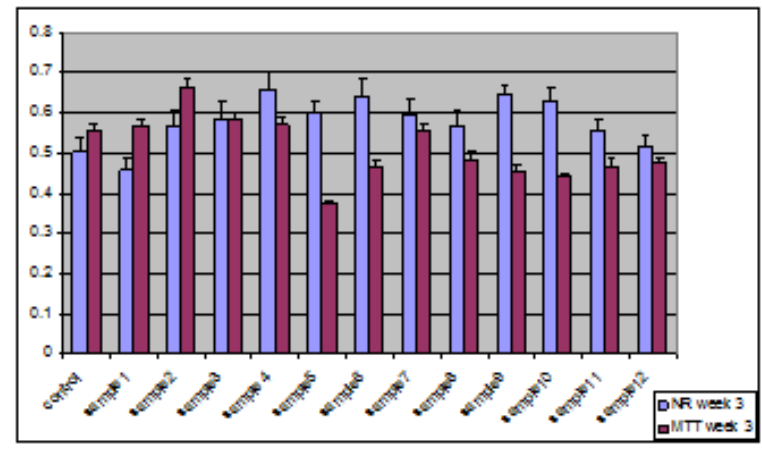

Week 3 responses of NR \& MTT assays for collected test materials were employed as controls and were incubated for the same time as test materials. Extracts were incubated for $24 \mathrm{~h}$ according to the dilution above with HepG2 cells. To investigate the leaching ability of different $\mathrm{PU}$ (unprocessed materials) after incubation in $\mathrm{dH}_{2} \mathrm{O}$ and PBS for different periods of time, neutral red uptake was measured spectrophotometrically to assess cell viability, ${ }^{25-28}$ while tetrazolium salt reduction (MTT test) was employed to measure cell viability. ${ }^{29-32}$ Furthermore, the same previous cytotoxicity methods as well as a cell proliferation method in the presence of processed biomaterials were investigated.

\section{Results}

Responses of NR and MTT assays for test HEP G2 cells.

It is apparent from Figure 1, that over a week 1 to 4 week sample period, control response varied by up to almost $50 \%$, although any major change was recorded for week 4 relative to the previous period, with MTT being relatively more consistent than NR. The need to accommodate baseline control variation prompted the re-presentation of data as percentage of control over time; Figure 1. Some individual materials demonstrated a more orthodox time-response than others; while maximal responses were lower for MTT than NR, the SEs of the former were also consistently smaller, although in both cases, the SE was always well within an acceptable range. The consistent trend was that of a significant decline in the raw cytotoxicity response over the first 3 weeks, followed by a modest recovery in week 4 .

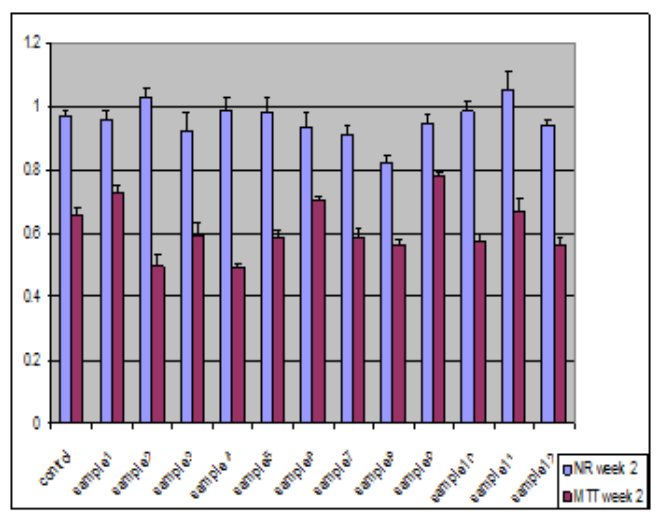

Week 2 responses of NR \& MTT assays for collected test materials

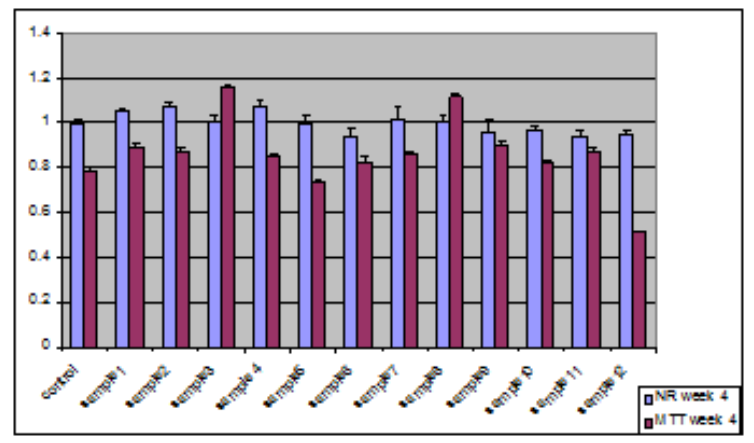

Week 4 responses of NR \& MTT assays for collected test materials

Figure I Responses of NR and MTT assays for test HEP G2 cells. 


\section{Comparative absorbance responses of NR assays for collected test}

The absorbance response from week 1-4 exposure showed that there was a general decrease in absorbance from week 1 with greatest decrease in week 3 for sample incubation (Figure 2).

\section{Responses of MTT assays for collected test materials}

The MTT assay absorbance response from week 1-4 exposure showed that there was a general decrease in absorbance from week 1 with greatest decrease in week 3 for sample incubation The was a gradual general increase at week 4 (Figure 3).

\section{Cell proliferation for Hep G2 and endothelial cells grown on 12 polymers}

The proliferation assay for both Hep G2 cells and Endothelial cells showed increased absorbance for Hep G2 cells compared to the endothelial cells with increasing polymer numbers (Figure 4)\% of control cell viability MTT (Endothelial cell) and NR for different PU's. Non- synchronized population responses are plotted against corresponding synchronized cells. The result indicated that the NR assay for the HepG2 cells grown on a 12 polyurethane surfaces showed an agreement between synchronized and non-synchronized cells. Synchronized cells gave NR responses between $90 \%-250 \%$ of control. The MTT assay for HepG2 cells grown on 12 replicate polyurethane surface showed no agreement between synchronized and non-synchronized cells (Figure 5). Synchronized cells gave MTT response clustered between $60 \& 110 \%$, with the latter giving an enhanced response over the control. Non-synchronized cell responses were all lower than control values. MTT assay for test materials using endothelial cell lines showed weak agreement between synchronized and non-synchronized endothelial cells. With a slope of 0.2677 and $\mathrm{r} 2=0.5089$.
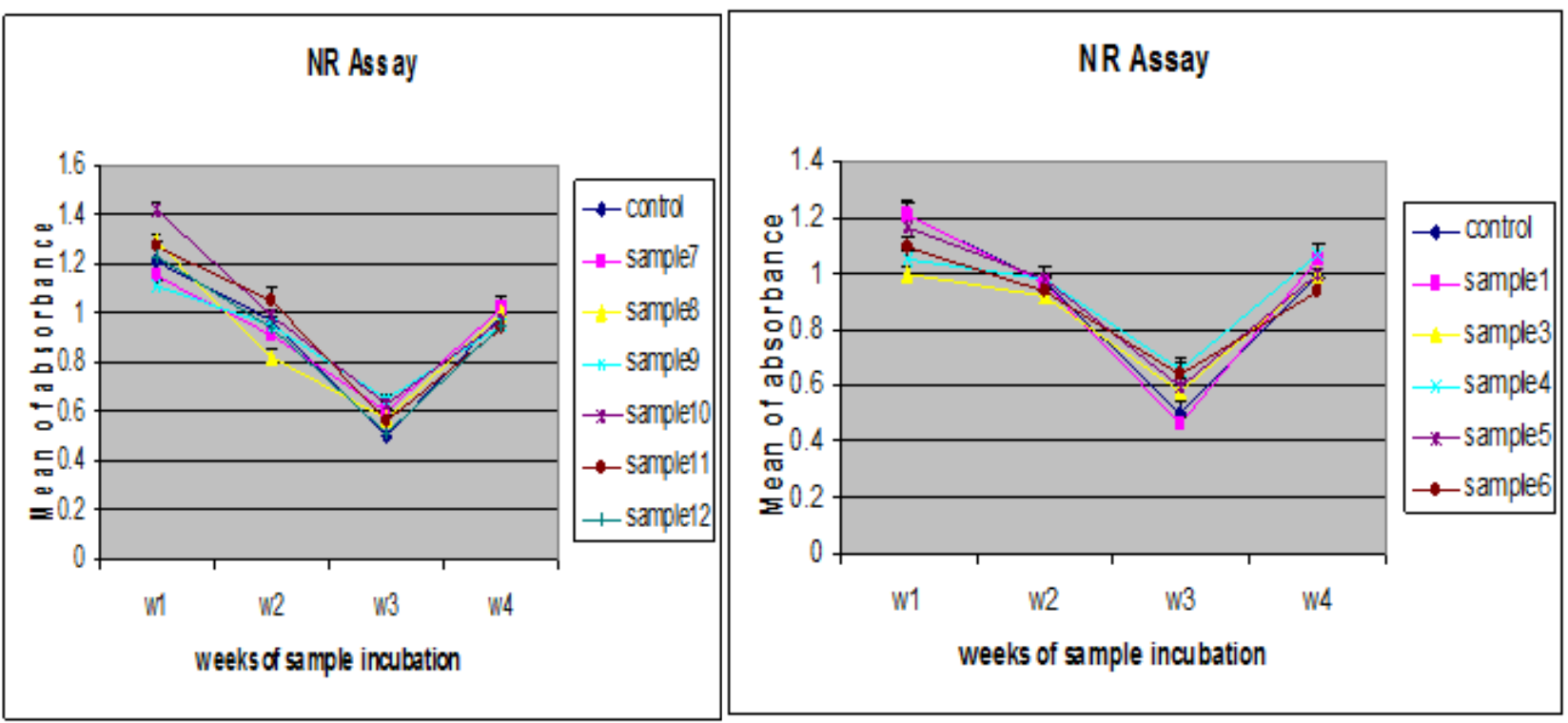

Figure 2 Mean Absorbance from Week I-4 responses of NR assays for collected test materials.
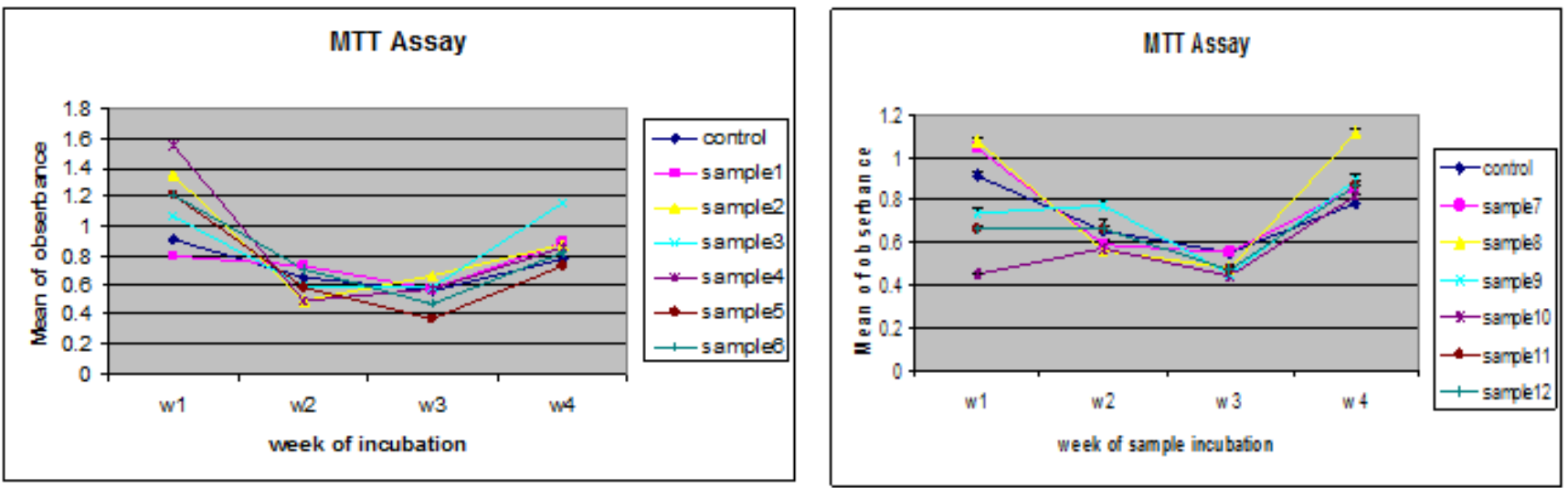

Figure 3 Week I-4 responses of MTT assays for collected test materials. 

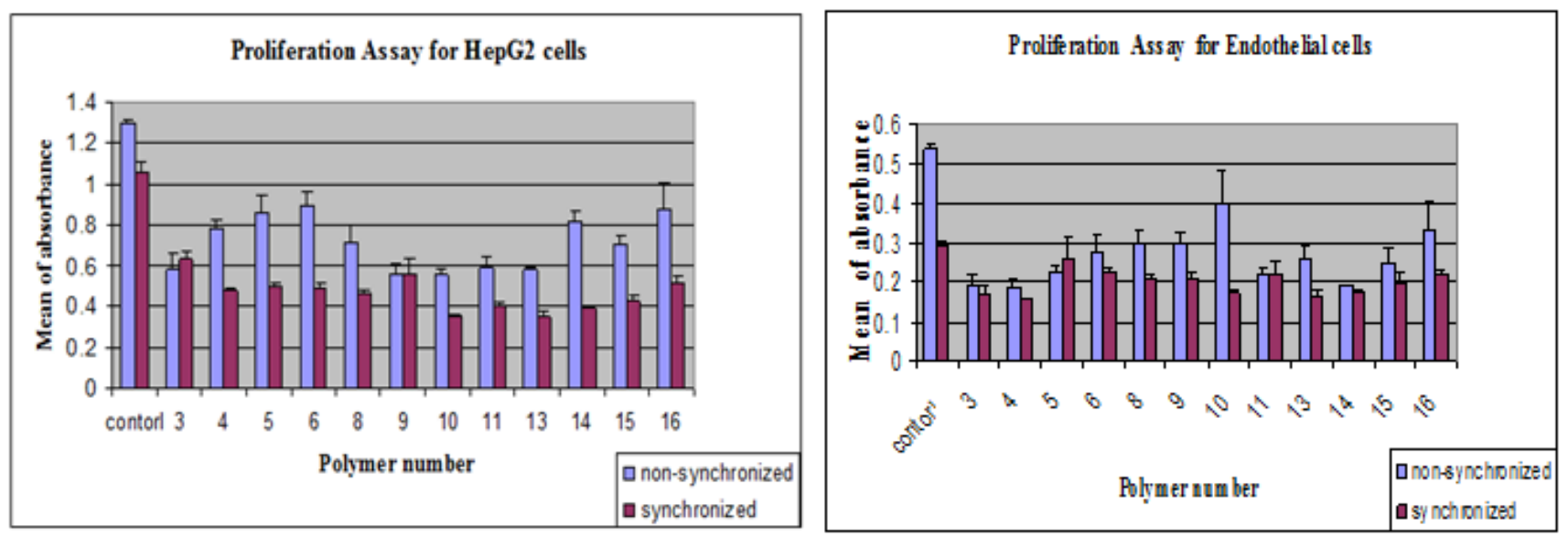

Figure 4 Cell proliferation for Hep G2 and endothelial cells grown on 12 polymers. Figure represents the Absorbance on polymer number.

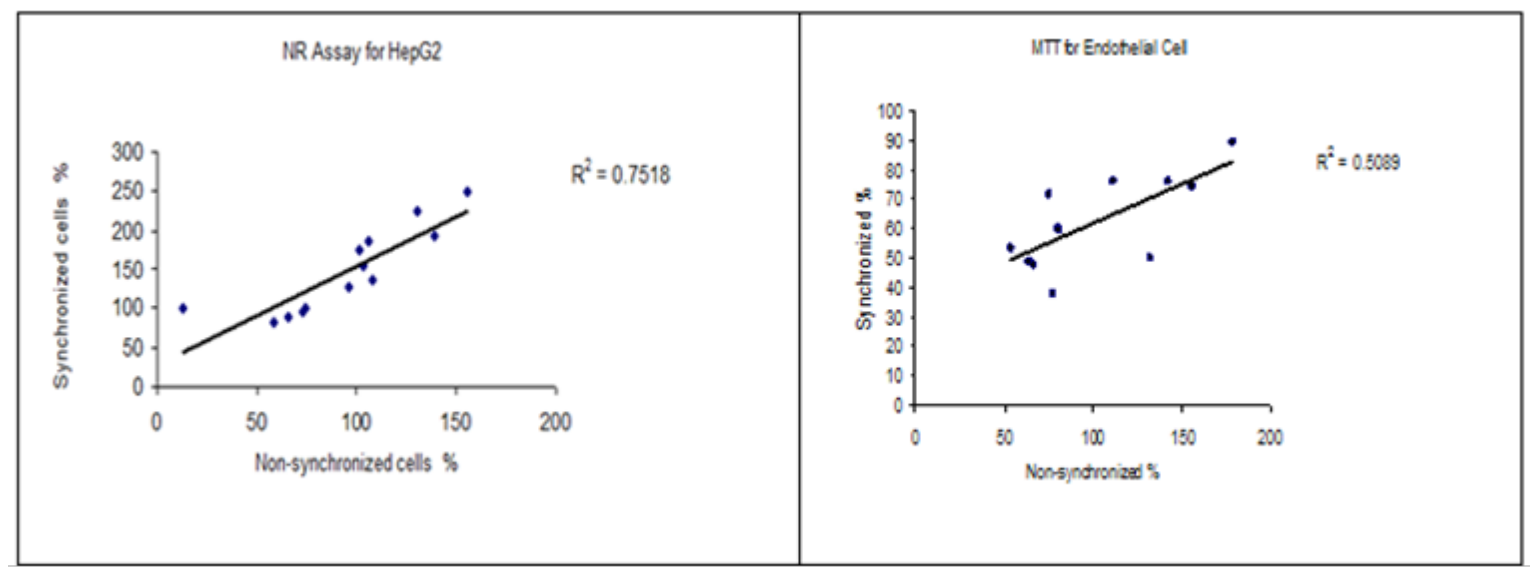

Figure $\mathbf{5} \%$ of control cell viability MTT (Endothelial cell) and NR for different PU's. Non- synchronized population responses are plotted against corresponding synchronized cells.

\section{Discussion}

Cell interactions with polymers have been predominantly studied in vitro, although the critical hurdle of any regulatory approval process involves in vivo trials. It is however unusual for a biomedical material to fail in vitro testing and subsequently prove to be functionally viable, thus, in vitro testing showed a low level of false negatives. It is likely that the effectiveness of the discriminating powers of in vitro analyses are vested in the fact that the techniques depend upon critical cell-material interactions that are similar to those that must occur in vivo and that the systems are sensitive to any indiscriminate toxicity. ${ }^{29-32}$ Published end points for cell-material interactions have included-cell viability, adhesion, spreading, aggregation, protein secretion, detoxification and motility. ${ }^{4,33-35}$ The two end points adopted in this study have been cell viability and proliferation. The core novel aspect of this thesis has been that the biocompatibility of different polyurethanes was investigated relative to 'their' gene expression profile. The biocompatibility of the implant material is closely related to the reaction between the surface the biomaterials and inflammatory host response., ${ }^{2,36}$ Cell behaviour on a surface is greatly influenced by the properties of the material. There are several factors that contribute to this. These may depend on individual materials characteristics, such as surface roughness and porosity, chemical reactions at the surface, corrosion and erosion properties of the material, and toxicity of small molecule leeching. ${ }^{9,27,37}$ Long ago, Folkman \& Moscona demonstrated that cell attraction properties of a polymer correlated closely with DNA synthesis. ${ }^{38}$ Cell adhesion is maximised on surfaces with intermediate wettability ${ }^{3,39}$ in the presence of serum. In the absence of serum, adhesion is improved on positively charged surfaces, and fibroblast spreading has been correlated with surface free energy ${ }^{11,16,40}$ though, in general, fibroblasts are far less demanding than other cell types. Collagen synthesis in fibroblasts has been correlated with contact angle, with higher rates of synthesis per cell for the most hydrophobic surfaces. ${ }^{41}$ Polymer surface attachment capacity for specific cell types can of course be enhanced by a number of treatments including an increase in the number of charged surface groups. Polyurethanes have emerged as biomaterials of interest for their elastic properties that could potentially alleviate the development of intimal heyperplasia (IH) at anastomastic regions. Polyurethanes are less reactive to plasma proteins and blood cells and provide mechanical properties similar to those of natural blood vessels. ${ }^{17,42-44}$ Poly (carbonate) polyurethane is a relatively new vascular graft material with a honeycomb microstructure developed using an entirely new type of chemistry and stress-free manufacturing process. This polycarbonate based polyurethane, which eliminates most ether linkages, is hydrolytically and oxidatively more stable and resistant to biodegradation., ${ }^{3,74}$ This materials has undergone 
numerous in vitro and in vivio studies, and its compliance and stiffness have been shown to match arterial compliance and rigidity to a greater than ePTFE and Dacron. ${ }^{1,46}$ Modifying the surface of existing synthetic grafts with regard to surface properties like hydrophilicity and presence of chemicals groups as well as by covalent attachment of bioactive substances, or incorporation of autologous vessel wall cells into vascular grafts, has been investigated..$^{29,47}$ In this study we used different polyurethane samples as test materials representing materials used in vascular tissue implants as well as new modified polyurethanes incorporating silicone. Agents released from cells may alter the characteristics of the materials surface. The surface was also changed due to the influence of protein adsorbed from plasma. ${ }^{5,12}$

\section{Acknowledgementss}

None.

\section{Conflict of interest}

The author declares that there is no conflict of interest.

\section{References}

1. Dartar MO, Yilmaz S, Kalayci A, et al. A comparison of the in vitro cytotoxicity of two root canal sealers. J Oral Rehabil. 2003;30(1):426-429.

2. Larz S. The importance of material preparation for the expression of cytotoxicity during in vitro evaluation of biomaterials. Journal of Endodotics. 2008;14(4):247-252.

3. Bruining MJ, Harrriet GT, Blaauwgeers M, et al. Biodegradable threedimentional networks of poly (dimethylamino ethyl methacrylate) Synthesis, characterization and in vitro studies of structural degradation and cytotoxicity. Biomaterials. 2000;21(6):595-604.

4. Granchi DA, Ciapetti GN, Savarino L, et al. Assessment of metal extract toxicity on human lymphocytes cultured in vitro. J Biomed Mater Res. 2006;31(6):183-191.

5. Ning L, Miao X, Takakuwa M, et al. Effect of Dental material HEMA monomer on human dental pulp cells. Artif Cells Blood Substit Immobil Biotechnol. 2009;21(1):85-90.

6. Wieslander A, Magnusson A, Kjeestrand P. Use of cell culture to predict toxicity of solid materials in blood contact. Biomater Artif Cells Artif Organs. 1990;18(3):367-374

7. Cascone MG, Tricoli P, Cerrai P, et al. Cell cultures in the biocompatibility study of synthetic materials. Cyotechnology. 2013;11:S137-139.

8. Kahaliw W, Hellman B, Engidawork E. Genotoxicity study of Ethiopian medicinal plant extracts on HepG2 cells. BMC Complement Altern Med. 2018;1;18(1):45.

9. Kalinina SA, Jagels A, Hickert S, et al. Detection of the Cytotoxic Penitrems A-F in Cheese from the European Single Market by HPLCMS/MS. J Agric Food Chem. 2018;66(5):1264-1269.

10. Natale A, Boeckmans J, Desmae T, et al. Hepatic cells derived from human skin progenitors show a typical phospholipidotic response upon exposure to amiodarone. Toxicol Lett. 2018;284:184-194.

11. Ren Z, Chen S, Qing T, et al. Endoplasmic reticulum stress and MAPK signaling pathway activation underlie leflunomide-induced toxicity in HepG2 Cells. Toxicology. 2017;392:11-21.

12. Alldridge LC. Annexin 1 regulates cell proliferation by disruption of cell morphology and inhibition of cyclin D1 expression through sustained activation of the ERK1/2 MAPK signal. Exp Cell Res. 2003;290(1):93-107.
13. Anderson JM. Biological Responses to Materials. Annual Review of Materials Research. 2001;31:81-110.

14. Barbier M, Laurier JF, Seigneurin D, et al. Modelling of cell proliferation: nuclear versus membrane labelling. Comptes Rendus Biologies. 2002;325:393-400.

15. Belanger MC, Marois Y. Haemocompatibility, biocompatibility, inflammatory and in vivo studies of primary reference materials lowdensity polyethylene and polydimethylsiloxane: A review. $J$ Biomed Mater Res. 2001;58:467-77.

16. Benson RS. Use of radiation in biomaterials science. Nuclear Instruments and Methods in Physics Research Section B: Beam Interactions with Materials and Atoms. 2002;191:752-757.

17. Curtis ASG. Cell reactions with biomaterials: the microscopies. Eur Cell Mater. 2001;1:59-65.

18. Hollert H, Dürr M, Erdinger L, et al. Cytotoxicity of settling particulate matter and sediments of the river Neckar (Germany) during a winter flood. Environ Toxicol Chem. 2000;19(3):528-534.

19. Keenihan SH. Successful skin grafts carry persuasive passengers. Trends in Immunology. 2002;23:431-432.

20. Pariente KB, Atala A. In vitro biocompatibility evaluation of naturally derived and synthetic biomaterials using normal human bladder smooth muscle cells. J Urol. 2002;167(4):1867-1871.

21. Queiroz TB, Santos GF, Ventura SC, et al. Cytotoxic and genotoxic potential of geraniol in peripheral blood mononuclear cells and human hepatoma cell line (HepG2). Genet Mol Res. 2017;27;16(3).

22. Pénzes Á, Mahmud Abdelwahab EM, Rapp J, et al. Toxicology studies of primycin-sulphate using a three-dimensional (3D) in vitro human liver aggregate model. Toxicol Lett. 2017;281:44-52.

23. Tomida $T$, Ishimura M, Iwaki M. A cell-based assay using HepaRG cells for predicting drug-induced phospholipidosis. J Toxicol Sci. 2017;42(5):641-650.

24. Di Nunzio M, Valli V, Tomás-Cobos L, et al. Is cytotoxicity a determinant of the different in vitro and in vivo effects of bioactives? BMC Complement Altern Med. 2017;7;17(1):453.

25. Luethi D, Liechti ME, Krähenbühl S. Mechanisms of hepatocellular toxicity associated with new psychoactive synthetic cathinones. Toxicology. 2017;387:57-66.

26. Séverin I, Lionti K, Dahbi L, et al. In vitro toxicity assessment of extracts derived from sol-gel coatings on polycarbonate intended to be used in food contact applications. Food Chem Toxicol. 2016;93:51-7.

27. Li TH, Jing CQ, Gao KL, et al. Cytotoxicity of 1-dodecyl-3methylimidazolium bromide on $\mathrm{HepG} 2$ cells. Genet $\mathrm{Mol}$ Res. 2015;14(4):13342-8.

28. Rodrigues RM, Heymans A, De Boe V, et al. Toxicogenomics-based prediction of acetaminophen-induced liver injury using human hepatic cell systems. Toxicol Lett. 2016;240(1):50-9.

29. Kettiger H, Sen Karaman D, Schiesser L, et al. Comparative safety evaluation of silica-based particles. Toxicol In Vitro. 2015;30(1):355-63.

30. Tafurt-Cardona Y, Suares-Rocha P, Fernandes TC, et al. Cytotoxic and genotoxic effects of two hair dyes used in the formulation of black color. Food Chem Toxicol. 2015;86:9-15.

31. Dartar MO, Yilmaz S, Kalayci A, et al. A comparison of the in vitro cytotoxicity of two root canal sealers. J Oral Rehabil. 2003;30(1):426-429.

32. Larz S. The importance of material preparation for the expression of cytotoxicity during in vitro evaluation of biomaterials. Journal of Endodotics. 2008;14(4):247-252. 
33. Bruining MJ, Harrriet GT, Blaauwgeers M, et al. Biodegradable threedimentional networks of poly (dimethylamino ethyl methacrylate). Synthesis, characterization and in vitro studies of structural degradation and cytotoxicity. Biomaterials. 2000;21(6):595-604.

34. Granchi DA, Ciapetti GN, Savarino L, et al. Assessment of metal extract toxicity on human lymphocytes cultured in vitro. J Biomed Mater Res. 1996;31(2):183-191.

35. Ning L, Miao X, Takakuwa M, et al. Effect of Dental material HEMA monomer on human dental pulp cells. Artif Cells Blood Substit Immobil Biotechnol. 1999;27(1):85-90.

36. Wieslander A, Magnusson A, Kjeestrand P. Use of cell culture to predict toxicity of solid materials in blood contact. Biomater Artif Cells Artif Organs. 2009;18(3):367-374.

37. Cascone MG, Tricoli P, Cerrai P, et al. Cell cultures in the biocompatibility study of synthetic materials. Cyotechnology. 1993;11(1):S137-139.

38. Kettiger H, Sen Karaman D, Schiesser L, et al. Comparative safety evaluation of silica-based particles. Toxicol In Vitro. 2015;30(1):355-363.

39. Tafurt Cardona Y, Suares Rocha P, Fernandes TC. Cytotoxic and genotoxic effects of two hair dyes used in the formulation of black color. Food Chem Toxicol. 2015;86:9-15.

40. Nikoloff N, Escobar L, Soloneski S, Larramendy ML. Comparative study of cytotoxic and genotoxic effects induced by herbicide S-metolachlor and its commercial formulation Twin Pack Gold ${ }^{\circledR}$ in human hepatoma (HepG2) cells. Food Chem Toxicol. 2013;62:777-81.
41. Seth R, Yang S, Choi S, et al. In vitro assessment of copper-induced toxicity in the human hepatoma line, Hep G2. Toxicol In vitro. 2004;18(4):501-9.

42. Figueiró LR, Dantas DC, Linden R, et al. Thirdhand tobacco smoke: procedures to evaluate cytotoxicity in cell cultures. Toxicol Mech Methods. 2016;26(5):355-61.

43. Alsalme A, Laeeq S, Dwivedi S, et al. Synthesis, characterization of $\alpha-$ amino acid Schiff base derived Ru/Pt complexes: Induces cytotoxicity in HepG2 cell via protein binding and ROS generation. Spectrochim Acta A Mol Biomol Spectrosc. 2016;15;163:1-7.

44. Nikoloff N, Larramendy ML, Soloneski S. Assessment of DNA damage, cytotoxicity, and apoptosis in human hepatoma (HepG2) cells after flurochloridone herbicide exposure. Food Chem Toxicol. 2014;65:233-41.

45. Nikoloff N, Escobar L, Soloneski S, et al. Comparative study of cytotoxic and genotoxic effects induced by herbicide S-metolachlor and its commercial formulation Twin Pack Gold $®$ in human hepatoma (HepG2) cells. Food Chem Toxicol. 2013;62:777-81.

46. Rudzok S, Krejči S, Graebsch C, et al. Toxicity profiles of four metals and 17 xenobiotics in the human hepatoma cell line HepG2 and the protozoa Tetrahymena pyriformis-a comparison. Environ Toxicol. 2011;26(2):171-86.

47. Dierickx PJ. Cytotoxicity of the MEIC reference chemicals in rat hepatoma-derived Fa32 cells. Toxicology. 2000;150(1-3):159-69. 